Check for updates

Cite this: RSC Adv., 2022, 12, 6248

\title{
Functionalized quinolizinium-based fluorescent reagents for modification of cysteine-containing peptides and proteins $\uparrow$
}

\author{
Karen Ka-Yan Kung, (D) ab Cai-fung Xu, ${ }^{a}$ Wa-Yi O, ${ }^{\text {ab }}$ Qiong Yu, ${ }^{a}$ Sai-Fung Chung, ${ }^{c}$ \\ Suet-Ying Tam, ${ }^{c}$ Yun-Chung Leung ${ }^{* c}$ and Man-Kin Wong (D)*ab
}

A series of quinolizinium-based fluorescent reagents were prepared by visible light-mediated goldcatalyzed cis-difunctionalization between quinolinium diazonium salts and electron-deficient alkynelinked phenylethynyl trimethylsilanes. The electron-deficient alkynyl group of the quinolizinium-based fluorescent reagents underwent nucleophilic addition reaction with the sulfhydryl group on cysteinecontaining peptides and proteins. The quinolizinium-based fluorescent reagents were found to function as highly selective reagents for the modification of cysteine-containing peptides and proteins with good to excellent conversions (up to 99\%). Moreover, the modified BCArg mutants bearing cationic quinolizinium compounds $1 \mathrm{~b}, 1 \mathrm{~d}, 1 \mathrm{e}$ and $1 \mathrm{~h}$ exhibit comparable activity in enzymatic and cytotoxicity assays to the unmodified one.

Received 13th November 2021 Accepted 21st January 2022

DOI: $10.1039 / \mathrm{d} 1 \mathrm{ra0} 8329 \mathrm{e}$

rsc.li/rsc-advances
Chemoselective chemical modification of peptides and proteins is of importance in chemical biology, ${ }^{5}$ which is useful to construct well-defined bioconjugates for biological studies and development of protein-based therapeutics and diagnostics. $^{6}$ In the past decades, lysine and cysteine are targets-ofinterest for chemical modification due to their high nucleophilicity. ${ }^{7,8}$ However, the high prevalence of lysine on protein

fluorescent scaffolds, fluorescein, rhodamine, coumarin, IPY, cyanine and, recently, Seoul-Fluor, have been intensively studied (Scheme 1a). ${ }^{2}$ However, these fluorescent materials generally have poor water-solubility, leading to limitation of versatility, sensitivity and quantitative capabilities. ${ }^{3}$ Some of the cationic heterocycles such as isoquinolinium, cinnolinium, quinolizinium, indolizinium, benzimidazolium, azinium and acridinium have been developed as fluorophores to improve water-solubility for biological research, ${ }^{1,4}$ but only a few examples have been reported on the unique properties of cationic fluorophores in photocatalysis ${ }^{1 c_{f}, g}$ and cellular imaging. ${ }^{3 b, c}$ Besides, these cationic fluorescent heterocycles were first studied as bioactive drug candidates and extensively employed as DNA intercalators. ${ }^{4 b}$ However, applications in chemoselective modification of peptides and proteins using these cationic heterocycles remain sparse.

${ }^{a}$ The Hong Kong Polytechnic University Shenzhen Research Institute, Shenzhen, 518057, China. E-mail: mankin.wong@polyu.edu.hk

${ }^{b}$ State Key Laboratory of Chemical Biology and Drug Discovery and Department of Applied Biology and Chemical Technology, The Hong Kong Polytechnic University, Hung Hom, Hong Kong, China

'Henry Cheng Research Laboratory for Drug Development, Lo Ka Chung Centre for Natural Anti-Cancer Drug Development, The Hong Kong Polytechnic University, Hung Hom, Hong Kong, China. E-mail: thomas.yun-chung.leung@polyu.edu.hk

$\dagger$ Electronic supplementary information (ESI) available. See DOI: 10.1039/d1ra08329e
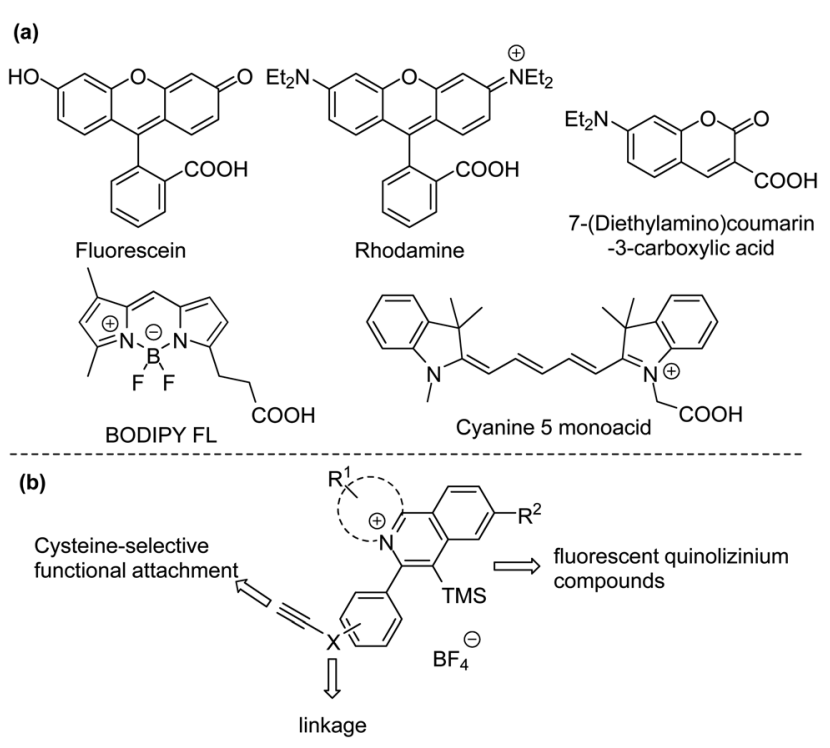

Scheme 1 (a) Selected examples of organic fluorescent dyes commonly used in bioconjugation reactions. (b) Our design of electron-deficient alkyne-containing quinolizinium compounds for cysteine modification. 
surfaces leads to the formation of protein conjugates with a poor level of regioselectivity. ${ }^{5 a}$ On the contrary, selective labeling of cysteine can be achieved by taking advantage of intrinsically low abundance $(1.7 \%)$ and by incorporation using site-directed mutagenesis, rendering cysteine as an ideal target on protein bioconjugations. Conventional cysteine modifications heavily relied on $S$-alkylation with $\alpha$-halocarbonyls and Michael addition to maleimides. Yet, owing to cross-reactivity, synthetic difficulties of $\alpha$-halocarbonyls and hydrolytic instability of the maleimide-based conjugates, Davis et al., ${ }^{9}$ Pentelute et al. ${ }^{10}$ our group ${ }^{11}$ and others ${ }^{12}$ have reported cysteine selective modifications in metal-free and/or metal-mediated manners. Most recent advances demonstrated the use of hypervalent iodine reagents for cysteine modification. ${ }^{13}$ Despite these new achievements, the development of easily accessible and water-soluble reagents for cysteine selective modification under mild reaction conditions is still an ongoing interest.

Most recently, our group has developed a new series of quinolizinium compounds as versatile cationic fluorescent heterocycles. ${ }^{14}$ These quinoliziniums exhibit tunable photophysical properties in the visible light region and large Stokes shifts, enriching the applications of visible-light-induced photocatalysis, ${ }^{14 a, b}$ cellular imaging ${ }^{\mathbf{1 4 a , c}}$ and molecular probes. ${ }^{\mathbf{1 4 c}}$ As such, the design of functionalized quinolizinum compounds by incorporation of the electron-deficient alkynyl group delivers easily accessible reagents for cysteine modification of peptides and proteins (Scheme 1). Along with our ongoing interest in the development of bioconjugation reactions, ${ }^{\mathbf{1 1}, 15}$ herein, we report a series of electron-deficient alkyne-linked quinolizinium compounds prepared from the visible light-mediated goldcatalyzed alkyne cis-difunctionalization. Photophysical properties of the newly developed quinolizinium compounds were also examined. We demonstrated that the fluorescent quinolizinium compounds could be used as efficient selective modification reagents for cysteine-containing peptides. The quinoliziniums also worked well for protein modification, including labelling a therapeutic Bacillus caldovelox arginase mutant (BCArg mutant). Enzymatic and anti-cancer activities of the modified BCArg mutants have also been studied.
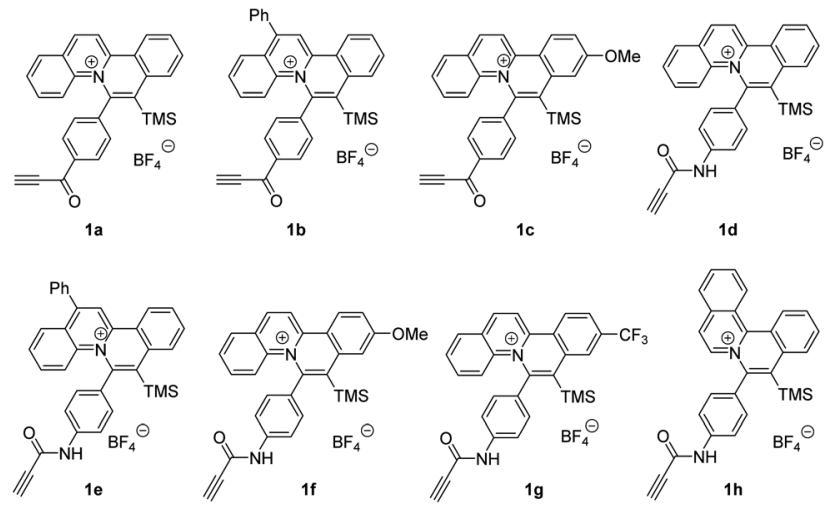

Fig. 1 Chemical structures of quinoliziniums $1 \mathrm{a}-1 \mathrm{~h}$.

\section{Results and discussion}

\section{Synthesis, characterization and photophysical properties of quinolizinium-based fluorescent reagents}

We first prepared a series of quinolizinium-based fluorescent reagents 1a-1h using visible light-mediated gold-catalyzed alkyne cis-difunctionalization developed by our group (Fig. 1). ${ }^{14 a}$ Using quinolizinium 1a as an example, it can be prepared by treatment of quinoline-substituted aryl diazonium 3a (0.12 mmol, 1.2 equiv.) and electron-deficient alkynecontaining phenylethynyl trimethylsilane 2a $(0.10 \mathrm{mmol}, 1$ equiv.) with $\mathrm{Ph}_{3} \mathrm{PAuCl}(10 \mathrm{~mol} \%)$ under irradiation of blue LEDs for $16 \mathrm{~h}$. Electron-deficient alkyne-linked quinolizinium 1b-1h were also prepared using the same method. Both alkynoic ketones 1a-1c and alkynoic amides 1d-1h were isolated in up to $49 \%$ yield after flash column purification. Our results revealed that electron-deficient alkynes have a high tolerance to the visible light-mediated gold catalysis reaction without losing the reactivity towards cysteine.

The photophysical properties of electron-deficient alkynelinked quinoliziniums $\mathbf{1 a - 1 h}$ were then measured by UV/Vis and fluorescence spectroscopies in dichloromethane (Table S3, ESI $\dagger$ ). The results showed that the maximum absorption of the 1a-1h was in the visible light region $\left(\lambda_{\text {abs }} 405-445 \mathrm{~nm}\right)$ and the maximum emission was between 478-555 $\mathrm{nm}$, with quantum yield $\left(\Phi_{\mathrm{F}}\right)$ of up to 0.22 . The molar absorptivity of these compounds was up to $15700 \mathrm{M}^{-1} \mathrm{~cm}^{-1}$. Moreover, alkynoic amides 1d-1h showed slightly larger Stokes shift than alkynoic ketones 1a-1c. In general, most of these findings were in line with our reported silyl-substituted quinoliziniums, ${ }^{\mathbf{1 4 a}}$ which demonstrated that this class of quinolizinium compounds could be amenable for the design of chemoselective reagents by incorporation of electron-deficient alkynes (alkynonic ketones and alkynoic amides) as one of the reactive functionalities towards peptide and protein labelling.

\section{Quinolizinium compounds as cysteine selective reagents}

Cysteine-containing peptide STSSSCNLSK and quinolizinium reagent 1a were set up as model substrates for condition screening with reference to our previous works. ${ }^{11 a}$ In brief, by treatment of peptide STSSSCNLSK $(0.1 \mathrm{mM})$ with $1 \mathrm{a}$ (1 equiv.) in $50 \mathrm{mM}$ PBS (pH 7.4)/DMSO (90:10) at $25^{\circ} \mathrm{C}$ for $6 \mathrm{~h}$, 1a-modified STSSSCNLSK and dimerized STSSSCNLSK were afforded in $89 \%$ and $6 \%$ conversions, respectively (entry 1 , Table 1 ). The total ion chromatogram of the crude mixture of 1a-modified STSSSCNLSK by LC-MS analysis showed the modification was efficient (Fig. S2, ESI $\dagger$ ). Selective attachment of 1 a to the cysteine sulfhydryl group of STSSSCNLSK via nucleophilic addition was confirmed by LC-MS/MS (Fig. S10, ESI $\dagger$ ). Neither the $\mathrm{N}$-terminal $\alpha$-amino group nor the side chains of serine, threonine and lysine were modified. Quinolizinium reagents $\mathbf{1 b}-\mathbf{1 h}$ also worked well in the reaction with STSSSCNLSK that gave $82-97 \%$ conversions (entries $2-8$ and Fig. S11-S24, ESI $\dagger$ ).

We then sought to demonstrate the chemoselectivity of the modification. Treatment of cysteine-containing peptides AYEMWCFSQR, AYEMWCFSQK, CSKFR, KSTFC and ASCGTN 
Table 1 Bioconjugation reaction of quinolizinium compounds with cysteine-containing peptides ${ }^{a}$

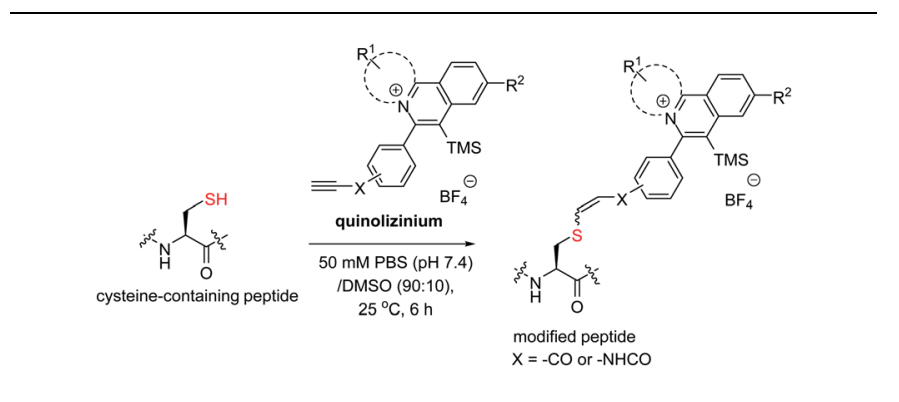

\begin{tabular}{|c|c|c|c|}
\hline Entry & Peptide & Quinolizinium & Conversion $^{b}(\%)$ \\
\hline 1 & STSSSCNLSK & $1 a$ & 89 \\
\hline 2 & STSSSCNLSK & $1 b$ & 95 \\
\hline 3 & STSSSCNLSK & $1 c$ & 82 \\
\hline 4 & STSSSCNLSK & $1 d$ & 97 \\
\hline 5 & STSSSCNLSK & $1 e$ & 94 \\
\hline 6 & STSSSCNLSK & 1f & 94 \\
\hline 7 & STSSSCNLSK & $1 \mathrm{~g}$ & 85 \\
\hline 8 & STSSSCNLSK & 1h & 95 \\
\hline 9 & AYEMWCFHQR & $1 a$ & 75 \\
\hline 10 & AYEMWCFHQR & $1 \mathrm{~b}$ & 99 \\
\hline 11 & AYEMWCFHQR & $1 \mathrm{c}$ & 47 \\
\hline 12 & AYEMWCFHQR & $1 d$ & 25 \\
\hline 13 & AYEMWCFHQR & $1 e$ & 99 \\
\hline 14 & AYEMWCFHQR & 1f & 96 \\
\hline 15 & AYEMWCFHQR & $1 \mathrm{~g}$ & 44 \\
\hline 16 & AYEMWCFHQR & $1 \mathrm{~h}$ & 96 \\
\hline 17 & AYEMWCFHQK & $1 a$ & 68 \\
\hline 18 & AYEMWCFHQK & $1 d$ & 47 \\
\hline 19 & AYEMWCFHQK & $1 \mathrm{~h}$ & 86 \\
\hline 20 & CSKFR & $1 a$ & 73 \\
\hline 21 & CSKFR & $1 d$ & 78 \\
\hline 22 & CSKFR & $1 \mathrm{~h}$ & 63 \\
\hline 23 & KSTFC & $1 a$ & 23 \\
\hline 24 & KSTFC & $1 d$ & 39 \\
\hline 25 & KSTFC & $1 \mathrm{~h}$ & 36 \\
\hline 26 & ASCGTN & $1 a$ & 94 \\
\hline 27 & ASCGTN & $1 d$ & 99 \\
\hline 28 & ASCGTN & $1 \mathrm{~h}$ & 99 \\
\hline
\end{tabular}

${ }^{a}$ Treatment of cysteine-containing peptide $(0.1 \mathrm{mM})$ with quinolizinium (1 equiv.) in $50 \mathrm{mM}$ PBS (pH 7.4)/DMSO (90:10) for 6 h. ${ }^{b}$ Determined by LC-MS analysis.

with quinolizinium compounds gave the corresponding modified peptides in up to $99 \%$ conversion (entries 9-28). MS/MS analysis revealed that only the cysteine residue was modified while other residues remained intact (Fig. S25-S64, ESI $\dagger$ ).

\section{Protein modification using quinolizinium compounds}

After screening the peptide modification, we further explored the present reaction for protein modification by employing electron-deficient alkyne-containing quinoliziniums (Table 2). Bovine serum albumin (BSA; PDB ID: 4F5S) and human serum albumin (HSA; PDB ID: 1AO6) with a single free cysteine residue were utilized for bioconjugation. Treatment of BSA $(0.1 \mathrm{mM})$ with quinolizinium reagent 1a (1-2 equiv.) in $50 \mathrm{mM}$ PBS (pH
Table 2 Bioconjugation reaction of quinolizinium compounds with proteins $^{a}$

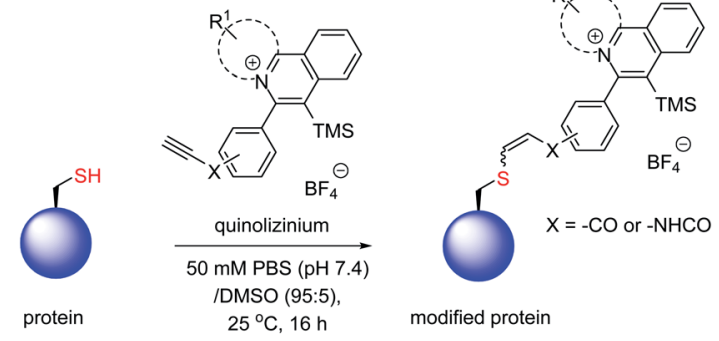

\begin{tabular}{llll}
\hline Entry & Protein & Quinolizinium & Conversion $^{b}(\%)$ \\
\hline 1 & BSA & 1a & $74^{c}$ \\
2 & BSA & $\mathbf{1 a}$ & 80 \\
3 & BSA & $\mathbf{1 a}$ & $74^{d}$ \\
4 & BSA & $\mathbf{1 b}$ & 65 \\
5 & BSA & $\mathbf{1 d}$ & 63 \\
6 & BSA & $\mathbf{1 e}$ & 28 \\
7 & BSA & $\mathbf{1 h}$ & 53 \\
8 & HSA & $\mathbf{1 a}$ & 70 \\
9 & HSA & $\mathbf{1 b}$ & 70 \\
10 & HSA & $\mathbf{1 d}$ & 75 \\
11 & HSA & $\mathbf{1 e}$ & 60 \\
12 & HSA & $\mathbf{1 h}$ & 59 \\
13 & Lysozyme & $\mathbf{1 a}$ & ND \\
14 & Lysozyme & $\mathbf{1 b}$ & ND \\
15 & Lysozyme & $\mathbf{1 d}$ & ND \\
16 & Lysozyme & $\mathbf{1 e}$ & ND \\
17 & Lysozyme & $\mathbf{1 h}$ &
\end{tabular}

${ }^{a}$ Treatment of proteins $(0.1 \mathrm{mM})$ with quinolizinium (2 equiv.) in 50 mM PBS (pH 7.4)/DMSO (95:5) for $16 \mathrm{~h} .{ }^{b}$ Determined by LC-MS analysis; ND $=$ not determined. ${ }^{c}$ Quinolizinium (1 equiv.) was used. ${ }^{d} 20 \mathrm{mM}$ Tris $\cdot \mathrm{HCl}(\mathrm{pH} 7.4) / \mathrm{DMSO}(95: 5)$ was used.

7.4)/DMSO (95:5) at $25^{\circ} \mathrm{C}$ for $16 \mathrm{~h}$ afforded 1a-modified BSA in $74 \%$ and $80 \%$ conversions (entries 1 and 2), respectively, as confirmed by LC-MS analysis with other residues remained intact (Fig. S66 and S67, ESI $\dagger$ ). In this regard, two equivalents of quinolizinium reagents were used for the bioconjugation of proteins as the unreacted reagents can be easily removed by size-exclusion chromatography (Bio-Rad Bio-Spin® ${ }^{\circledR}$ 6). The reaction also worked well in $20 \mathrm{mM}$ Tris $\cdot \mathrm{HCl}(\mathrm{pH} 7.4)(74 \%$, entry 3; Fig. S68, ESI†). ${ }^{11 a}$ Use of $\mathbf{1 b}, \mathbf{1 d}, \mathbf{1 e}$ or $\mathbf{1 h}$ (2 equiv.) afforded the corresponding modified BSA in $28-65 \%$ conversions (entries 4-7 and Fig. S69-S72, ESI $\dagger$ ). Apart from BSA, HSA was also found to have $59-70 \%$ conversions (entries $8-12$ and Fig. S77-S81, ESI $\dagger$ ). In addition, trypsin digestion of modified BSA and HSA was conducted. After LC-MS/MS analysis of tryptic proteins, the modification was only found on Cys34 residue on peptide fragments, GLVLIAFSQYLQQCPFDEHVK of modified BSA and ALVLIAFAQYLQQCPFEDHVK of modified HSA, while other residues remained intact (Fig. S73-S75, S82 and S83, ESI $†$ ). Notably, no modification was observed with lysozyme (PDB ID: 3LYZ), which contains no free cysteine residue (Entries 13-17). These results indicated that our functionalized 
Table 3 SDS-PAGE analysis of $1 \mathrm{~b}$-modified proteins

$1 \mathrm{~b}$

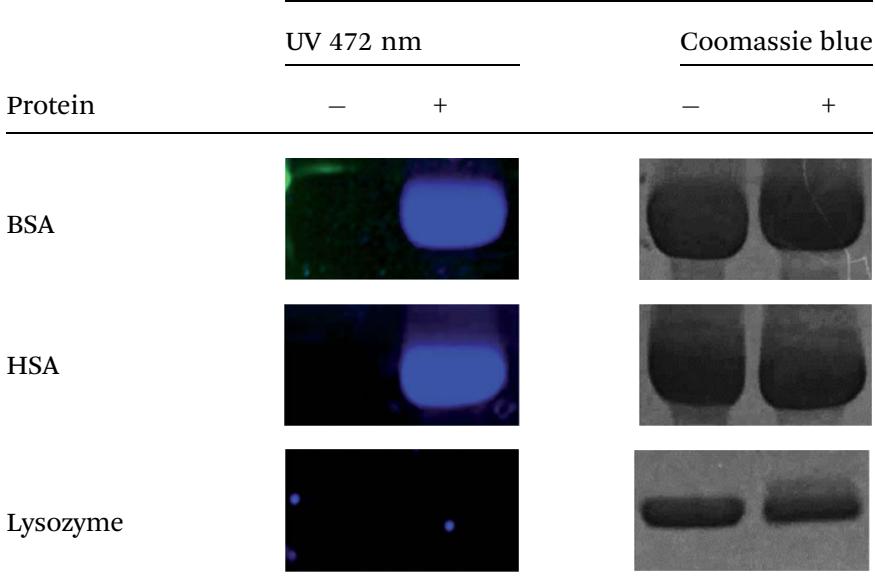

quinolizinium compounds could be employed as efficient chemoselective reagents in protein modification.

Labelling of proteins with fluorescent reagents can work as protein stains in SDS-PAGE gel and has the potential for in vivo tracking the uptake and physiological activities. Therefore, we performed the use of the present functionalized quinoliziniumbased fluorescent reagents for labelling of proteins. As shown in SDS-PAGE analysis (Table 3), it was found that $\mathbf{1} \mathbf{b}$-modified BSA and HSA (from entries 4 and 9, Table 2) gave a fluorescent signal excitation at UV $472 \mathrm{~nm}$ in SDS-PAGE protein analysis. Treatment of $\mathbf{1 b}$ with lysozyme gave no fluorescent signal (from entry 14, Table 2). The results of protein conjugates from SDS-PAGE analysis were found to be consistent to that of LC-MS analysis.

\section{Biological studies of modified BCArg mutants}

Human arginase is a metalloenzyme, in which its PEGylated form was the first generation of therapeutic protein with an extended half-life that has been reported to treat hepatocellular carcinoma, ${ }^{16}$ lung cancer, ${ }^{17}$ pancreatic cancer $^{18}$ and immunotherapy-resistant melanoma ${ }^{19}$ in preclinical and clinical trials, respectively. Then, Bacillus caldovelox arginase mutant (BCArg mutant) and its PEGylated form (at the position of Cys ${ }^{161}$ ) have has been established as the second generation of therapeutic protein for the treatment of a broad spectrum of cancers such as lung and cervical cancers. ${ }^{20}$ Apart from BSA and HSA, we also employed the use of present quinolizinium reagents to selectively modify cysteine residue of the BCArg mutant. BCArg mutant $(0.1 \mathrm{mM})$ was first treated with quinolizinium $1 \mathrm{a}$ ( 1 and 2 equiv.) in $20 \mathrm{mM}$ Tris $\cdot \mathrm{HCl}(\mathrm{pH} 7.4) / \mathrm{DMSO}$ (95:5) at $25{ }^{\circ} \mathrm{C}$ for $16 \mathrm{~h}$ to give 1a-modified BCArg mutant in $60 \%$ and $82 \%$ conversions, respectively (Table 4; Fig. S85 and S86, ESI $\dagger$ ). Then, $\mathbf{1 b}, \mathbf{1 d}, \mathbf{1 e}$ and $\mathbf{1 h}$ ( 2 equiv.) gave the corresponding modified BCArg mutants in $78-84 \%$ conversions (Table 4 and Fig. S87-S90, ESI $†$ ). Excellent cysteine selectivity was demonstrated by the tryptic peptide fragments of 1e- and 1h-modified BCArg mutants found in LC-MS/MS analysis (Fig. S91 and S92, ESI $\dagger$ ).

To study the influence of the cationic quinolizinium-based reagents used in the modification on the biological properties of therapeutic proteins, we then evaluated enzyme activities and anti-cancer properties of the modified BCArg mutants with the unmodified analogue (Table 4). The enzymatic properties of the 1b-, 1d- and 1h-modified BCArg mutants were comparable to that of the unmodified BCArg mutant, while 1a- and 1e-modified BCArg mutants displayed slightly lower enzymatic activities. The anti-cancer properties of the unmodified and modified BCArg mutants were then examined using human colon cancer cell line LoVo (CCL-229 ${ }^{\mathrm{TM}}$, American Type Culture Collection). Experimental $\mathrm{IC}_{50}$ values indicated that the anticancer efficacy of all modified BCArg mutants were comparable to that of the unmodified one. These findings indicated that the modified BCArg mutants retained their biological activities and anticancer efficacies after the bioconjugation with no significant influence over the cationic charge of the quinolizinium reagents.

\section{Conclusions}

In this work, we have developed a series of electron-deficient alkyne-containing quinoliziniums as useful reagents for cysteine-selective modification of peptides and proteins with up to $99 \%$ conversion. The present method was successfully applied on selective modification of proteins, including the therapeutic protein (BCArg mutant). Most of the resulting cationic quinolizinium-modified BCArg mutants have

Table 4 Enzymatic activities and $\mathrm{IC}_{50}$ values of BCArg mutant and modified BCArg mutants

\begin{tabular}{|c|c|c|c|}
\hline Sample $^{a}$ & Conversion $^{b}(\%)$ & $\begin{array}{l}\text { Specific activity } \\
\left(\mathrm{U} \mathrm{mg}^{-1}\right)\end{array}$ & $\mathrm{IC}_{50}$ values for LoVo $\left(\mathrm{U} \mathrm{mL}^{-1}\right)$ \\
\hline BCArg mutant & - & $202 \pm 20$ & $0.067 \pm 0.012$ \\
\hline 1a-Modified BCArg mutant & $60^{c}$ & - & - \\
\hline 1a-Modified BCArg mutant & 82 & $138 \pm 16$ & $0.077 \pm 0.025$ \\
\hline 1b-Modified BCArg mutant & 80 & $179 \pm 7$ & $0.082 \pm 0.030$ \\
\hline 1d-Modified BCArg mutant & 84 & $185 \pm 18$ & $0.062 \pm 0.008$ \\
\hline 1e-Modified BCArg mutant & 78 & $130 \pm 9$ & $0.079 \pm 0.022$ \\
\hline 1h-Modified BCArg mutant & 80 & $169 \pm 13$ & $0.065 \pm 0.004$ \\
\hline
\end{tabular}

${ }^{a}$ Treatment of proteins $\left(0.1 \mathrm{mM}\right.$ ) with quinolizinium (2 equiv.) in $20 \mathrm{mM}$ Tris $\cdot \mathrm{HCl}(\mathrm{pH} 7.4) / \mathrm{MSO}(95: 5)$ for $16 \mathrm{~h} .{ }^{b}$ Determined by LC-MS analysis.

${ }^{c}$ Quinolizinium (1 equiv.) was used. 
comparable enzymatic activities and anticancer efficacies to those of the unmodified one.

\section{Experimental}

All reagents were commercially available and used without further purification. All peptides ( $>98 \%$ purity) were directly purchased from GL Biochem (Shanghai) Ltd. BSA, HSA and lysozyme were purchased from Sigma Aldrich and used without further purification. Milli-Q ${ }^{\circledR}$ water used as reaction solvent in peptide and protein modification, as well as LC-MS analysis, was deionised using a Milli-Q ${ }^{\circledR}$ Gradient A10 system (Millipore, Billerica, USA). Flash column chromatography was performed using silica gel 60 (230-400 mesh ASTM) with ethyl acetate $/ n$ hexane or methanol/dichloromethane as eluent. All NMR spectra were recorded on a Bruker DPX-400 spectrometer. All chemical shifts are quoted on the scale in ppm using TMS or residual solvent as the internal standard. Coupling constants $(J)$ are reported in Hertz $(\mathrm{Hz})$ with the following splitting abbreviations: $\mathrm{s}=$ singlet, br $\mathrm{s}=$ broad singlet, $\mathrm{d}=$ doublet, $\mathrm{dd}$ $=$ double doublet, $\mathrm{t}=$ triplet and $\mathrm{m}=$ multiplet. All mass spectra were obtained on an ESI source of Agilent 6540 Ultra High Definition (UHD) Accurate-Mass Q-TOF LC/MS systems in the positive and negative ion modes.

All the photochemical experiments were performed in a custom made "light box" with 4 reaction vessels surrounded by 16 blue LED light bulbs. The temperature was maintained by a fan attached to the "light box". A voltage transformer was connected with the blue LEDs and employed to monitor the power of the light source $(P=U \times I=14.3 \mathrm{~V} \times 2.3 \mathrm{~A}=32.9 \mathrm{~W})$. 4 reactions were performed in the "light box" every time for measurement of the reaction yields. The emission spectra of the blue LEDs revealed a maximum emission wavelength of the light source at $\lambda_{\max }=468 \mathrm{~nm}$ (Fig. S1, ESI $\dagger$ ).

\section{General procedure for visible light-mediated gold-catalyzed} synthesis of quinolizinium compounds $1 \mathrm{a}-1 \mathrm{~h}$

A solution of aryl diazonium salts $3 \mathbf{a}-\mathbf{3 e}$ (1.2 equiv.), silyl substituted alkynes 2 a or $2 \mathbf{b}\left(0.5 \mathrm{mmol}, 1\right.$ equiv.), $\mathrm{Ph}_{3} \mathrm{PAuCl}$ (10 mol\%) and $5 \mathrm{~mL}$ of $\mathrm{CH}_{3} \mathrm{CN}$ was added into a $20 \mathrm{~mL}$ test tube. The test tube capped with a rubber septum was evacuated and refilled with nitrogen three times. After that, the tube containing the reaction mixture was irradiated with blue LEDs for $16 \mathrm{~h}$. After the reaction completed, the mixture was concentrated under reduced pressure. The crude product was purified by flash column chromatography using methanol/ dichloromethane as eluent to afford compound 1a-1h.

Compound 1a. Yellow powder, 49\% yield. ${ }^{1} \mathrm{H}$ NMR (400 $\left.\mathrm{MHz}, \mathrm{CD}_{3} \mathrm{CN}\right) \delta 9.00(\mathrm{~d}, J=9.0 \mathrm{~Hz}, 1 \mathrm{H}), 8.90(\mathrm{t}, J=7.7 \mathrm{~Hz}, 2 \mathrm{H})$, $8.43(\mathrm{~d}, J=8.2 \mathrm{~Hz}, 1 \mathrm{H}), 8.26-8.20(\mathrm{~m}, 3 \mathrm{H}), 8.20-8.13(\mathrm{~m}, 1 \mathrm{H})$, 8.09-8.03 (m, 1H), $7.70(\mathrm{t}, J=7.5 \mathrm{~Hz}, 1 \mathrm{H}), 7.66(\mathrm{~d}, J=8.4 \mathrm{~Hz}$, $2 \mathrm{H}), 7.52(\mathrm{~d}, J=8.9 \mathrm{~Hz}, 1 \mathrm{H}), 7.37-7.30(\mathrm{~m}, 1 \mathrm{H}), 4.06(\mathrm{~s}, 1 \mathrm{H}), 0.07$ $(\mathrm{d}, J=3.3 \mathrm{~Hz}, 9 \mathrm{H}) .{ }^{13} \mathrm{C} \mathrm{NMR}\left(100 \mathrm{MHz}, \mathrm{CDCl}_{3}\right) \delta 176.23,149.39$, 144.58, 143.82, 143.11, 137.40, 136.77, 136.16, 135.28, 134.45, 132.40, 131.07, 130.71, 130.19, 129.75, 129.39, 129.16, 129.11, 128.35, 127.48, 125.31, 125.04, 119.24, 82.92, 79.92, 2.34. HRMS
(ESI) $m / z$ calcd for $\mathrm{C}_{29} \mathrm{H}_{24} \mathrm{NOSi}^{+}\left[\mathrm{M}-\mathrm{BF}_{4}{ }^{-}\right]^{+}$430.1622, found 430.1623; $\mathrm{m} / z$ calcd for $\mathrm{BF}_{4}{ }^{-}\left[\mathrm{M}-\mathrm{C}_{29} \mathrm{H}_{24} \mathrm{NOSi}^{+}\right]^{-}$87.0035, found 87.0034

Compound 1b. Yellow powder, 25\% yield. ${ }^{1} \mathrm{H}$ NMR $(400$ MHz, acetone- $\left.d_{6}\right) \delta 9.35(\mathrm{~d}, J=8.4 \mathrm{~Hz}, 1 \mathrm{H}), 9.27(\mathrm{~s}, 1 \mathrm{H}), 8.59(\mathrm{~d}, J$ $=8.0 \mathrm{~Hz}, 1 \mathrm{H}), 8.35(\mathrm{~d}, J=8.6 \mathrm{~Hz}, 2 \mathrm{H}), 8.34-8.25(\mathrm{~m}, 1 \mathrm{H}), 8.21-$ $8.12(\mathrm{~m}, 2 \mathrm{H}), 8.07-7.99(\mathrm{~m}, 4 \mathrm{H}), 7.90(\mathrm{~d}, J=8.9 \mathrm{~Hz}, 1 \mathrm{H}), 7.83-$ $7.75(\mathrm{~m}, 4 \mathrm{H}), 7.56-7.47(\mathrm{~m}, 1 \mathrm{H}), 4.61(\mathrm{~s}, 1 \mathrm{H}), 0.17(\mathrm{~s}, 9 \mathrm{H}) .{ }^{13} \mathrm{C}$ NMR $\left(100 \mathrm{MHz}\right.$, acetone- $\left.d_{6}\right) \delta 196.12,189.90,184.16,173.96$, 168.85 , 165.37, 157.32, 157.19, 157.03, 155.09, 154.50, 153.05, $150.89,150.47,150.22,149.57,149.45,149.41,149.35,148.44$, $148.25,148.01,147.73,147.44,146.32$, 145.40, 138.26, 103.91, 99.90, 49.58, 49.39, 49.20, 49.00, 48.81, 48.62, 48.43, 21.34. HRMS (ESI) $\mathrm{m} / z$ calcd for $\mathrm{C}_{35} \mathrm{H}_{28} \mathrm{NOSi}^{+}\left[\mathrm{M}-\mathrm{BF}_{4}{ }^{-}\right]^{+}$506.1935, found 506.1951; $\mathrm{m} / \mathrm{z}$ calcd for $\mathrm{BF}_{4}{ }^{-}\left[\mathrm{M}-\mathrm{C}_{35} \mathrm{H}_{28} \mathrm{NOSi}^{+}\right]^{-}$87.0035, found 87.0034 .

Compound 1c. Brown powder, $17 \%$ yield. ${ }^{1} \mathrm{H}$ NMR $(400 \mathrm{MHz}$, $\left.\mathrm{CDCl}_{3}\right) \delta 9.00(\mathrm{~d}, J=8.3 \mathrm{~Hz}, 1 \mathrm{H}), 8.93(\mathrm{~d}, J=9.0 \mathrm{~Hz}, 1 \mathrm{H}), 8.75(\mathrm{~d}$, $J=7.9 \mathrm{~Hz}, 1 \mathrm{H}), 8.27$ (d, $J=7.2 \mathrm{~Hz}, 2 \mathrm{H}), 8.07$ (d, $J=7.8 \mathrm{~Hz}, 1 \mathrm{H})$, $7.66-7.54(\mathrm{~m}, 5 \mathrm{H}), 7.44(\mathrm{~d}, J=8.6 \mathrm{~Hz}, 1 \mathrm{H}), 7.24(\mathrm{t}, J=7.8 \mathrm{~Hz}$, $1 \mathrm{H}), 4.12(\mathrm{~s}, 3 \mathrm{H}), 3.62(\mathrm{~s}, 1 \mathrm{H}), 0.13(\mathrm{~s}, 9 \mathrm{H}) .{ }^{13} \mathrm{C}$ NMR $(100 \mathrm{MHz}$, $\left.\mathrm{CDCl}_{3}\right) \delta 176.19,164.59,148.66,145.13,143.70,141.75,137.40$, $135.98,133.65$, 132.36, 130.67, 130.19, 129.81, 129.57, 128.85, 128.38, 124.90, 124.10, 120.84, 119.57, 119.10, 111.28, 82.85, 79.92, 56.43, 31.56, 30.32, 2.40. HRMS (ESI) $\mathrm{m} / \mathrm{z}$ calcd for

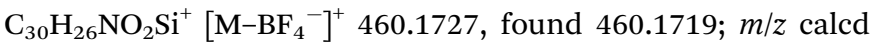
for $\mathrm{BF}_{4}{ }^{-}\left[\mathrm{M}-\mathrm{C}_{30} \mathrm{H}_{26} \mathrm{NOSi}^{+}\right]^{-}$87.0035, found 87.0033.

Compound 1d. Yellow powder, 41\% yield. ${ }^{1} \mathrm{H}$ NMR $(400$ MHz, acetone- $\left.d_{6}\right) \delta 10.19(\mathrm{~s}, 1 \mathrm{H}), 9.29(\mathrm{~d}, J=9.0 \mathrm{~Hz}, 1 \mathrm{H}), 9.12$ (dd, $J=13.1,8.7 \mathrm{~Hz}, 2 \mathrm{H}), 8.53(\mathrm{~d}, J=8.2 \mathrm{~Hz}, 1 \mathrm{H}), 8.38$ (d, $J=$ $7.9 \mathrm{~Hz}, 1 \mathrm{H}), 8.25$ (t, $J=7.5 \mathrm{~Hz}, 1 \mathrm{H}), 8.11$ (t, $J=7.7 \mathrm{~Hz}, 1 \mathrm{H}), 7.90$ $(\mathrm{d}, J=8.4 \mathrm{~Hz}, 2 \mathrm{H}), 7.85(\mathrm{~d}, J=9.0 \mathrm{~Hz}, 1 \mathrm{H}), 7.79(\mathrm{t}, J=7.5 \mathrm{~Hz}$, $1 \mathrm{H}), 7.65(\mathrm{~d}, J=8.5 \mathrm{~Hz}, 2 \mathrm{H}), 7.50(\mathrm{t}, J=8.0 \mathrm{~Hz}, 1 \mathrm{H}), 3.85(\mathrm{~s}, 1 \mathrm{H})$, 0.16 (s, 9H). ${ }^{13} \mathrm{C}$ NMR (100 MHz, acetone- $\left.d_{6}\right) \delta$ 169.64, 166.67, 162.03 , 160.83, 157.29, 156.92, 154.73, 154.39, 153.82, 152.95, $150.28,149.70,149.33,149.21,149.17,149.11,147.04,145.60$, 145.36, 139.99, 139.92, 138.83, 49.58, 49.39, 49.20, 49.00, 48.81, 48.62, 48.43, 21.39. HRMS (ESI) $m / z$ calcd for $\mathrm{C}_{29} \mathrm{H}_{25} \mathrm{~N}_{2} \mathrm{OSi}^{+}[\mathrm{M}-$ $\left.\mathrm{BF}_{4}{ }^{-}\right]^{+} 445.1731$, found $445.1790 ; \mathrm{m} / z$ calcd for $\mathrm{BF}_{4}{ }^{-}\left[\mathrm{M}-\mathrm{C}_{29^{-}}\right.$ $\left.\mathrm{H}_{25} \mathrm{NOSi}^{+}\right]^{-}$87.0035, found 87.0032.

Compound 1e. Deep yellow powder, $45 \%$ yield. ${ }^{1} \mathrm{H}$ NMR $(400$ $\left.\mathrm{MHz}, \mathrm{CD}_{3} \mathrm{CN}\right) \delta 9.19(\mathrm{~s}, 1 \mathrm{H}), 8.96(\mathrm{~d}, J=8.5 \mathrm{~Hz}, 1 \mathrm{H}), 8.89(\mathrm{~s}, 1 \mathrm{H})$, $8.38(\mathrm{~d}, J=8.3 \mathrm{~Hz}, 1 \mathrm{H}), 8.12(\mathrm{t}, J=7.5 \mathrm{~Hz}, 1 \mathrm{H}), 8.06(\mathrm{~d}, J=$ $7.5 \mathrm{~Hz}, 1 \mathrm{H}), 8.00(\mathrm{t}, J=7.5 \mathrm{~Hz}, 1 \mathrm{H}), 7.92(\mathrm{dd}, J=6.4,2.9 \mathrm{~Hz}, 2 \mathrm{H})$, $7.77-7.68(\mathrm{~m}, 6 \mathrm{H}), 7.62(\mathrm{t}, J=7.6 \mathrm{~Hz}, 1 \mathrm{H}), 7.50(\mathrm{~d}, J=8.0 \mathrm{~Hz}$, $2 \mathrm{H}), 7.35(\mathrm{t}, J=8.6 \mathrm{~Hz}, 1 \mathrm{H}), 3.45(\mathrm{~s}, 1 \mathrm{H}), 0.10(\mathrm{~s}, 9 \mathrm{H}) .{ }^{13} \mathrm{C} \mathrm{NMR}$ $\left(100 \mathrm{MHz}\right.$, acetone- $\left.d_{6}\right) \delta 173.53,168.68,157.42,157.30,155.12$, 154.32 , 153.32, 153.00, 150.76, 150.20, 150.08, 149.29, 149.21, 149.11, 148.02, 147.54, 147.33, 146.11, 145.28, 139.94, 138.18, 95.63, 49.58, 49.39, 49.19, 49.00, 48.81, 48.62, 48.42, 21.37. HRMS (ESI) $m / z$ calcd for $\mathrm{C}_{35} \mathrm{H}_{29} \mathrm{~N}_{2} \mathrm{OSi}^{+}\left[\mathrm{M}-\mathrm{BF}_{4}{ }^{-}\right]^{+}$521.2044, found $521.2052 ; \mathrm{m} / z$ calcd for $\mathrm{BF}_{4}{ }^{-}\left[\mathrm{M}-\mathrm{C}_{35} \mathrm{H}_{29} \mathrm{~N}_{2} \mathrm{OSi}^{+}\right]^{-}$87.0035, found 87.0032 .

Compound 1f. Yellow powder, $48 \%$ yield. ${ }^{1} \mathrm{H}$ NMR $(400 \mathrm{MHz}$, $\left.\mathrm{CD}_{3} \mathrm{CN}\right) \delta 9.23(\mathrm{~s}, 1 \mathrm{H}), 8.81-8.74(\mathrm{~m}, 2 \mathrm{H}), 8.66(\mathrm{~d}, J=9.0 \mathrm{~Hz}, 1 \mathrm{H})$, $8.11(\mathrm{~d}, J=7.8 \mathrm{~Hz}, 1 \mathrm{H}), 7.69(\mathrm{~d}, J=8.5 \mathrm{~Hz}, 2 \mathrm{H}), 7.65-7.60(\mathrm{~m}$, $2 \mathrm{H}), 7.59(\mathrm{~d}, J=2.2 \mathrm{~Hz}, 1 \mathrm{H}), 7.50(\mathrm{~d}, J=8.9 \mathrm{~Hz}, 1 \mathrm{H}), 7.40(\mathrm{~d}, J=$ 
$8.5 \mathrm{~Hz}, 2 \mathrm{H}), 7.30$ (dd, $J=11.7,4.3 \mathrm{~Hz}, 1 \mathrm{H}), 4.11(\mathrm{~s}, 3 \mathrm{H}), 3.45$ (s, $1 \mathrm{H}), 0.10(\mathrm{~s}, 9 \mathrm{H}) .{ }^{13} \mathrm{C} \mathrm{NMR}\left(100 \mathrm{MHz}, \mathrm{CD}_{3} \mathrm{OD}\right) \delta 165.86,152.41$, 150.02, 148.25, 141.86, 137.87, 135.94, 134.02, 133.64, 130.60, 130.47, 130.08, 129.70, 126.39, 121.75, 121.40, 120.74, 119.42, 111.51, 77.20, 56.96, 2.28. HRMS (ESI) $\mathrm{m} / \mathrm{z}$ calcd for

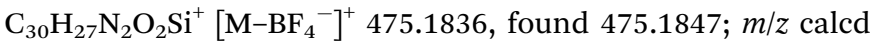
for $\mathrm{BF}_{4}{ }^{-}\left[\mathrm{M}-\mathrm{C}_{30} \mathrm{H}_{27} \mathrm{~N}_{2} \mathrm{OSi}^{+}\right]^{-}$87.0035, found 87.0034.

Compound 1g. Yellow powder, $43 \%$ yield. ${ }^{1} \mathrm{H}$ NMR $(400$ $\left.\mathrm{MHz}, \mathrm{CD}_{3} \mathrm{OD}\right) \delta 9.24(\mathrm{~d}, J=9.0 \mathrm{~Hz}, 2 \mathrm{H}), 9.08(\mathrm{~d}, J=8.9 \mathrm{~Hz}, 1 \mathrm{H})$, 8.58 (s, $1 \mathrm{H}), 8.30$ (dd, $J=19.0,8.2 \mathrm{~Hz}, 2 \mathrm{H}), 7.78(\mathrm{dd}, J=12.3$, $5.7 \mathrm{~Hz}, 4 \mathrm{H}), 7.54-7.42(\mathrm{~m}, 3 \mathrm{H}), 3.85$ (s, 1H), $0.16(\mathrm{~s}, 9 \mathrm{H}) .{ }^{13} \mathrm{C}$ NMR $\left(100 \mathrm{MHz}, \mathrm{CD}_{3} \mathrm{OD}\right) \delta 144.33,138.08,136.32,133.96$, 133.12, 131.30, 130.70, 130.36, 129.92, 126.62, 125.50, 121.46, 119.88, 49.64, 49.43, 49.21, 49.00, 48.79, 48.57, 48.36, 2.17. ${ }^{19} \mathrm{~F}$ NMR (376 MHz, DMSO-d ${ }_{6}$ ) $\delta-61.80,-148.29$. HRMS (ESI) $m / z$ calcd for $\mathrm{C}_{30} \mathrm{H}_{24} \mathrm{~F}_{3} \mathrm{~N}_{2} \mathrm{OSi}^{+}\left[\mathrm{M}-\mathrm{BF}_{4}{ }^{-}\right]^{+}$513.1605, found 513.1616; $m / z$ calcd for $\mathrm{BF}_{4}{ }^{-}\left[\mathrm{M}-\mathrm{C}_{30} \mathrm{H}_{24} \mathrm{~F}_{3} \mathrm{~N}_{2} \mathrm{OSi}^{+}\right]^{-}$87.0035, found 87.0036 .

Compound 1h. Yellow powder, $10 \%$ yield. ${ }^{1} \mathrm{H}$ NMR $(400$ $\left.\mathrm{MHz}, \mathrm{CD}_{3} \mathrm{OD}\right) \delta 9.12(\mathrm{~d}, J=8.5 \mathrm{~Hz}, 1 \mathrm{H}), 9.05(\mathrm{~d}, J=8.4 \mathrm{~Hz}, 1 \mathrm{H})$, $8.60(\mathrm{~d}, J=8.3 \mathrm{~Hz}, 1 \mathrm{H}), 8.36(\mathrm{~d}, J=7.4 \mathrm{~Hz}, 1 \mathrm{H}), 8.31$ (d, $J=$ $7.8 \mathrm{~Hz}, 1 \mathrm{H}), 8.22(\mathrm{dd}, J=15.7,7.6 \mathrm{~Hz}, 2 \mathrm{H}), 8.16(\mathrm{dd}, J=18.0$, $9.7 \mathrm{~Hz}, 1 \mathrm{H}), 8.11(\mathrm{~d}, J=7.4 \mathrm{~Hz}, 1 \mathrm{H}), 8.07$ (t, $J=7.8 \mathrm{~Hz}, 1 \mathrm{H}), 7.96$ $(\mathrm{d}, J=8.5 \mathrm{~Hz}, 2 \mathrm{H}), 7.62(\mathrm{~d}, J=8.6 \mathrm{~Hz}, 2 \mathrm{H}), 3.86(\mathrm{~s}, 1 \mathrm{H}), 0.22(\mathrm{~s}$, 9H). ${ }^{13} \mathrm{C}$ NMR (100 MHz, CD 3 OD) $\delta$ 152.55, 150.28, 145.69, $142.47,139.33$, 136.23, 134.96, 134.43, 133.79, 133.42, 131.96, 131.06, 130.88, 129.47, 128.55, 126.13, 122.67, 121.99, 77.29, 49.64, 49.43, 49.22, 49.00, 48.79, 48.58, 48.37, 1.69. HRMS (ESI) $m / z$ calcd for $\mathrm{C}_{29} \mathrm{H}_{25} \mathrm{~N}_{2} \mathrm{OSi}^{+}\left[\mathrm{M}-\mathrm{BF}_{4}{ }^{-}\right]^{+}$445.1731, found 445.1741; $\mathrm{m} / z$ calcd for $\mathrm{BF}_{4}{ }^{-}\left[\mathrm{M}-\mathrm{C}_{29} \mathrm{H}_{25} \mathrm{~N}_{2} \mathrm{OSi}^{+}\right]^{-}$87.0035, found 87.0033.

\section{Author contributions}

M.-K. Wong and Y.-C. Leung conceptualized and supervised the study. C.-F. Xu and K. K.-Y. Kung performed the organic synthesis in this work. C.-F. Xu, K. K.-Y. Kung and Q. Yu performed characterization of all compounds. K. K.-Y. Kung and W.-Y. O performed UV/Vis and fluorescence measurements, bioconjugation experiments and mass spectroscopy analysis of this work. S.-F. Chung and S.-Y. Tam purified and measured the biological activities of the anticancer proteins. K. K.-Y. Kung prepared this paper.

\section{Conflicts of interest}

M.-K. Wong, K. K.-Y. Kung, Q. Yu and W.-Y. O filed a patent on electron-deficient alkyne-containing quinolizinium compounds (CN113402538A).

\section{Acknowledgements}

We gratefully acknowledge the financial support from the Shenzhen Science and Technology Innovation Commission (JCYJ20170818104257975), Hong Kong Research Grants Council (15300117), the State Key Laboratory of Chemical Biology and Drug Discovery, The Hong Kong Polytechnic University (G-ZVVG and G-UACN), and Innovation and Technology Commission (PRP/075/19FX). We acknowledge the support on mass spectrometry from the University Research Facility in Life Sciences (ULS) of The Hong Kong Polytechnic University.

\section{Notes and references}

1 (a) H. Uoyama, K. Goushi, K. Shizu, H. Nomura and C. Adachi, Nature, 2012, 492, 234-238; (b) X. Li, X. Gao, W. Shi and H. Ma, Chem. Rev., 2014, 114, 590-659; (c) N. A. Romero and D. A. Nicewicz, Chem. Rev., 2016, 116, 10075-10166; (d) G. J. Hedley, A. Ruseckas and I. D. W. Samuel, Chem. Rev., 2017, 117, 796-837; (e) W. Sun, M. Li, J. Fan and X. Peng, Acc. Chem. Res., 2019, 52, 2818-2831; $(f)$ M. V. Bobo, J. J. Kuchta and A. K. Vannucci, Org. Biomol. Chem., 2021, 19, 4816-4834; (g) A. Vega-Peñaloza, J. Mateos, X. Companyó, M. EscuderoCasao and L. Dell'Amico, Angew. Chem., Int. Ed., 2021, 60, 1082-1097.

2 (a) A. Loudet and K. Burgess, Chem. Rev., 2007, 107, 48914932; (b) H. Kobayashi, M. Ogawa, R. Alford, P. L. Choyke and Y. Urano, Chem. Rev., 2010, 110, 2620-2640; (c) K. M. Dean and A. E. Palmer, Nat. Chem. Biol., 2014, 10, 512-523; (d) E. Kim, Y. Lee, S. Lee and S. B. Park, Acc. Chem. Res., 2015, 48, 538-547.

3 (a) U. Resch-Genger, M. Grabolle, S. Cavaliere-Jaricot, R. Nitschke and T. Nann, Nat. Methods, 2008, 5, 763-775; (b) W. Xu, Z. Zeng, J.-H. Jiang, Y.-T. Chang and L. Yuan, Angew. Chem., Int. Ed., 2016, 55, 13658-13699; (c) Z. Xu and L. Xu, Chem. Commun., 2016, 52, 1094-1119.

4 (a) S. P. Pitre, C. D. McTiernan and J. C. Scaiano, ACS Omega, 2016, 1, 66-76; (b) D. Sucunza, A. M. Cuadro, J. Alvarez-Builla and J. J. Vaquero, J. Org. Chem., 2016, 81, 10126-10135; (c) I. F. A. Mariz, S. N. Pinto, A. M. Santiago, J. M. G. Martinho, J. Recio, J. J. Vaquero, A. M. Cuadro and E. Maçôas, Commun. Chem., 2021, 4, 142.

5 (a) N. Stephanopoulos and M. B. Francis, Nat. Chem. Biol., 2011, 7, 876-884; (b) C. D. Spicer and B. G. Davis, Nat. Commun., 2014, 5, 4740; (c) O. Boutureira and G. J. L. Bernardes, Chem. Rev., 2015, 115, 2174-2195; (d) O. Koniev and A. Wagner, Chem. Soc. Rev., 2015, 44, 54955551; (e) C. Zhang, E. V. Vinogradova, A. M. Spokoyny, S. L. Buchwald and B. L. Pentelute, Angew. Chem., Int. Ed., 2019, 58, 4810-4839.

6 (a) N. Krall, F. P. da Cruz, O. Boutureira and G. J. L. Bernardes, Nat. Chem., 2016, 8, 103-113; (b) E. A. Hoyt, M. S. D. Cal Pedro, B. L. Oliveira and J. L. Bernardes Gonçalo, Nat. Rev. Chem., 2019, 3, 147-171; (c) M. Haque, N. Forte and J. R. Baker, Chem. Commun., 2021, 57, 10689-10702; (d) B. X. Li, D. K. Kim, S. Bloom, R. Y. C. Huang, J. X. Qiao, W. R. Ewing, D. G. Oblinsky, G. D. Scholes and D. W. C. MacMillan, Nat. Chem., 2021, 13, 902-908; (e) M. S. Kang, T. W. S. Kong, J. Y. X. Khoo and T.-P. Loh, Chem. Sci., 2021, 12, 13613-13647.

7 (a) S. Choi, S. Connelly, N. Reixach, I. A. Wilson and J. W. Kelly, Nat. Chem. Biol., 2010, 6, 133-139; (b) S. Asano, J. T. Patterson, T. Gaj and C. F. Barbas III, Angew. Chem., 
Int. Ed., 2014, 53, 11783-11786; (c) A. R. Nanna, X. Li, E. Walseng, L. Pedzisa, R. S. Goydel, D. Hymel, T. R. Burke Jr, W. R. Roush and C. Rader, Nat. Commun., 2017, 8, 1112; (d) M. J. Matos, B. L. Oliveira, N. Martínez-Sáez, A. Guerreiro, P. M. S. D. Cal, J. Bertoldo, M. Maneiro, E. Perkins, J. Howard, M. J. Deery, J. M. Chalker, F. Corzana, G. Jiménez-Osés and G. J. L. Bernardes, J. Am. Chem. Soc., 2018, 140, 4004-4017.

8 (a) J. M. Chalker, G. J. L. Bernardes, Y. A. Lin and B. G. Davis, Chem.-Asian J., 2009, 4, 630-640; (b) S. B. Gunnoo and A. Madder, ChemBioChem, 2016, 17, 529-553.

9 (a) G. J. L. Bernardes, J. M. Chalker, J. C. Errey and B. G. Davis, J. Am. Chem. Soc., 2008, 130, 5052-5053; (b) J. M. Chalker, Y. A. Lin, O. Boutureira and B. G. Davis, Chem. Commun., 2009, 3714-3716.

10 (a) A. M. Spokoyny, Y. Zou, J. J. Ling, H. Yu, Y.-S. Lin and B. L. Pentelute, J. Am. Chem. Soc., 2013, 135, 5946-5949; (b) E. V. Vinogradova, C. Zhang, A. M. Spokoyny, B. L. Pentelute and S. L. Buchwald, Nature, 2015, 526, 687691; (c) C. Zhang, M. Welborn, T. Zhu, N. J. Yang, M. S. Santos, T. Van Voorhis and B. L. Pentelute, Nat. Chem., 2016, 8, 120-128; (d) M. Jbara, S. Pomplun, C. K. Schissel, S. W. Hawken, A. Boija, I. Klein, J. Rodriguez, S. L. Buchwald and B. L. Pentelute, J. Am. Chem. Soc., 2021, 143, 11788-11798.

11 (a) H.-Y. Shiu, T.-C. Chan, C.-M. Ho, Y. Liu, M.-K. Wong and C.-M. Che, Chem.-Eur. J., 2009, 15, 3839-3850; (b) H.-Y. Shiu, H.-C. Chong, Y.-C. Leung, M.-K. Wong and C.-M. Che, Chem.-Eur. J., 2010, 16, 3308-3313; (c) H.-Y. Shiu, M.-K. Wong and C.-M. Che, Chem. Commun., 2011, 47, 4367-4369; (d) A. O.-Y. Chan, J. L.-L. Tsai, V. K.-Y. Lo, G.-L. Li, M.-K. Wong and C.-M. Che, Chem. Commun., 2013, 49, 1428-1430; (e) K. K.-Y. Kung, H.-M. Ko, J.-F. Cui, H.-C. Chong, Y.-C. Leung and M.-K. Wong, Chem. Commun., 2014, 50, 11899-11902; (f) J.-R. Deng, S.-F. Chung, A. S.-L. Leung, W.-M. Yip, B. Yang, M.-C. Choi, J.-F. Cui, K. K.-Y. Kung, Z. Zhang, K.-W. Lo, Y.-C. Leung and M.-K. Wong, Commun. Chem., 2019, 2, 93.

12 (a) J. Yu, X. Yang, Y. Sun and Z. Yin, Angew. Chem., Int. Ed., 2018, 57, 11598-11602; (b) Y. Zhang, X. Zhou, Y. Xie, M. M. Greenberg, Z. Xi and C. Zhou, J. Am. Chem. Soc., 2017, 139, 6146-6151; (c) M. S. Messina, J. M. Stauber, M. A. Waddington, A. L. Rheingold, H. D. Maynard and A. M. Spokoyny, J. Am. Chem. Soc., 2018, 140, 7065-7069.

13 (a) A. K. Mishra, R. Tessier, D. P. Hari and J. Waser, Angew. Chem., Int. Ed., 2021, 60, 17963-17968; (b) S. A. Byrne, M. J. Bedding, L. Corcilius, D. J. Ford, Y. Zhong, C. Franck, M. Larance, J. P. Mackay and R. J. Payne, Chem. Sci., 2021, 12, 14159-14166.
14 (a) J.-R. Deng, W.-C. Chan, N. C.-H. Lai, B. Yang, C.-S. Tsang, B. C.-B. Ko, S. L.-F. Chan and M.-K. Wong, Chem. Sci., 2017, 8, 7537-7544; (b) W.-M. Yip, Q. Yu, A. Tantipanjaporn, W.-C. Chan, J.-R. Deng, B. C.-B. Ko and M.-K. Wong, Org. Biomol. Chem., 2021, 19, 8507-8515; (c) W.-Y. O, W.-C. Chan, C. Xu, J.-R. Deng, B. C.-B. Ko and M.-K. Wong, RSC Adv., 2021, 11, 33294-33299.

15 (a) A. O.-Y. Chan, C.-M. Ho, H.-C. Chong, Y.-C. Leung, J.-S. Huang, M.-K. Wong and C.-M. Che, J. Am. Chem. Soc., 2012, 134, 2589-2598; (b) K. K.-Y. Kung, G.-L. Li, L. Zou, H.-C. Chong, Y.-C. Leung, K.-H. Wong, V. K.-Y. Lo, C.-M. Che and M.-K. Wong, Org. Biomol. Chem., 2012, 10, 925-930; (c) G.-L. Li, K. K.-Y. Kung and M.-K. Wong, Chem. Commun., 2012, 48, 4112-4114; (d) G.-L. Li, K. K.-Y. Kung, L. Zou, H.-C. Chong, Y.-C. Leung, K.-H. Wong and M.-K. Wong, Chem. Commun., 2012, 48, 3527-3529; (e) K. K.-Y. Kung, V. K.-Y. Lo, H.-M. Ko, G.-L. Li, P.-Y. Chan, K.-C. Leung, Z. Zhou, M.-Z. Wang, C.-M. Che and M.-K. Wong, Adv. Synth. Catal., 2013, 355, 2055-2070; $(f)$ K. K.-Y. Kung, K.-F. Wong, K.-C. Leung and M.-K. Wong, Chem. Commun., 2013, 49, 6888-6890; (g) F. K.-C. Leung, J.-F. Cui, T.-W. Hui, K. K.-Y. Kung and M.-K. Wong, Asian J. Org. Chem., 2015, 4, 533-536; (h) H.-Y. Sit, B. Yang, K. K.-Y. Kung, J. S.-L. Tam and M.-K. Wong, ChemPlusChem, 2019, 84, 1739-1743; (i) J.-R. Deng, N. C.-H. Lai, K. K.-Y. Kung, B. Yang, S.-F. Chung, A. S.-L. Leung, M.-C. Choi, Y.-C. Leung and M.-K. Wong, Commun. Chem., 2020, 3, 67; (j) H.-M. Ko, J.-R. Deng, J.-F. Cui, K. K.-Y. Kung, Y.-C. Leung and M.-K. Wong, Bioorg. Med. Chem., 2020, 28, 115375.

16 P. N.-M. Cheng, T.-L. Lam, W.-M. Lam, S.-M. Tsui, A. W.-M. Cheng, W.-H. Lo and Y.-C. Leung, Cancer Res., 2007, 67, 309-317.

17 (a) S.-F. Chung, C.-F. Kim, S.-Y. Tam, M.-C. Choi, P.-K. So, K.-Y. Wong, Y.-C. Leung and W.-H. Lo, Appl. Microbiol. Biotechnol., 2020, 104, 3921-3934; (b) Y. Zhang, S.-F. Chung, S.-Y. Tam, Y.-C. Leung and X. Guan, Cancer Lett., 2021, 502, 58-70.

18 K.-M. Yu, T. P.-S. Pang, M. Cutler, M. Tian, L. Huang, J. Y.-N. Lau, S.-F. Chung, T. W.-H. Lo and T. Y.-C. Leung, Life Sci., 2021, 264, 118674.

19 C. De Santo, P. Cheng, A. Beggs, S. Egan, A. Bessudo and F. Mussai, J. Hematol. Oncol., 2018, 11, 68.

20 (a) S.-F. Chung, C.-F. Kim, H.-Y. Chow, H.-C. Chong, S.-Y. Tam, Y.-C. Leung and W.-H. Lo, Int. J. Mol. Sci., 2020, 21, 7445; (b) S.-F. Chung, C.-F. Kim, S.-Y. Kwok, S.-Y. Tam, Y. W. Chen, H.-C. Chong, S.-L. Leung, P.-K. So, K.-Y. Wong, Y.-C. Leung and W.-H. Lo, Int. J. Mol. Sci., 2020, 21, 4234. 